\title{
MRNA Sequencing
}

National Cancer Institute

\section{Source}

National Cancer Institute. mRNA Sequencing. NCI Thesaurus. Code C129432.

A procedure that can determine the RNA sequences for all or part of the poly-A tailcontaining messenger RNA transcripts in an individual. 